\title{
Glacier mass-balance fluctuations in the Pacific Northwest and Alaska, USA
}

\author{
Edward G. JOSBERGER, ${ }^{1}$ William R. BIDLAKE, ${ }^{1}$ Rod S. MARCH, ${ }^{2}$ Ben W. KENNEDY ${ }^{2}$ \\ ${ }^{1}$ Washington Water Science Center, US Geological Survey, 934 Broadway, Suite 300, Tacoma, WA 98402, USA \\ E-mail: ejosberg@usgs.gov \\ ${ }^{2}$ Alaska Science Center, US Geological Survey, 3400 Shell Street, Fairbanks, AK 99701-7245, USA
}

\begin{abstract}
The more than 40 year record of net and seasonal mass-balance records from measurements made by the United States Geological Survey on South Cascade Glacier, Washington, and Wolverine and Gulkana Glaciers, Alaska, shows annual and interannual fluctuations that reflect changes in the controlling climatic conditions at regional and global scales. As the mass-balance record grows in length, it is revealing significant changes in previously described glacier mass-balance behavior, and both inter-glacier and glacier-climate relationships. South Cascade and Wolverine Glaciers are strongly affected by the warm and wet maritime climate of the northeast Pacific Ocean. Their net balances have generally been controlled by winter accumulation, with fluctuations that are strongly related to the Pacific Decadal Oscillation (PDO). Recently, warm dry summers have begun to dominate the net balance of the two maritime glaciers, with a weakening of the correlation between the winter balance fluctuations and the PDO. Non-synchronous periods of positive and negative net balance for each glacier prior to 1989 were followed by a 1989-2004 period of synchronous and almost exclusively negative net balances that averaged $-0.8 \mathrm{~m}$ for the three glaciers.
\end{abstract}

\section{INTRODUCTION}

The United States Geological Survey (USGS) Water Resources Discipline glacier-monitoring program began as a result of the International Geophysical Year (IGY; 1957-58) (Meier and others, 1971), and now that the Third International Polar Year (IPY; 2007-08) is approaching, it is fitting to examine the unique records from measurements of seasonal mass balances that clearly document dramatic glacier shrinkage that has occurred over nearly 50 years. The adage that 'glaciers are an indicator of climate' generally refers to changes in glacier length, which are difficult to interpret and relate to short-term climate fluctuations because a glacier is continually adjusting (responding) to past changes in mass balance. Arendt and others (2002) found little correlation between the rate of length change and the rate of thickness change. However, seasonal measurements of glacier mass balance, winter accumulation and summer ablation directly integrate the annual variations of key climate variables, including precipitation and temperature. Observations from mountain glaciers are particularly valuable because they provide measurements of climatic conditions from remote regions with sparse observations and at higher altitudes than most climate stations.

The three glaciers of the USGS glacier-monitoring program are South Cascade Glacier in the North Cascade Mountains of Washington; Wolverine Glacier near the southern coast of Alaska; and Gulkana Glacier in the interior of Alaska. These glaciers were chosen to represent the large number of glaciers in each region. Each region is subject to a different climate: South Cascade and Wolverine Glaciers are both maritime glaciers, and although separated by $2200 \mathrm{~km}$ they consequently receive deep winter snowpacks, as much as $8 \mathrm{~m}$, and undergo substantial melting during summer. Gulkana Glacier is a continental glacier shielded from the moisture-bearing storms of the Gulf of Alaska by the east-west-trending Chugach, Wrangell and
Talkeetna mountain ranges to the south. Hodge and others (1998) fully describe the characteristics of each glacier, while March (1998), Mayo and others (2004) and Bidlake and others (2005) provide complete details on the measurement program at each glacier. Although glacier mass balances can be estimated by many different techniques, mass-balance records considered in this paper are those assembled from on-glacier measurements begun on each glacier in the late 1950s or mid-1960s.

The net mass balance of a glacier is the net change in mass between successive balance minima $\left(b_{n}\right)$, usually summer surfaces, including changes in both ice and snow thickness, averaged over the area of the glacier. The balance year can be divided into two parts, the winter season, dominated by accumulation $\left(b_{w}\right)$, and the summer season, dominated by snow- and ice melt $\left(b_{\mathrm{s}}\right)$. Changes in thicknesses of ice and snow are adjusted by their density, and the balances are reported in meters of water equivalent (mw.e.). The data are typically acquired from changes in surface heights of snow or ice measured on stakes, snow distribution on the glacier is determined from probing the snowpack on the glacier, and the vertical distribution of snow density is obtained from weighing known volumes of snow. For these glaciers the error is usually \pm 0.1 to $\pm 0.2 \mathrm{~m}$. Mayo and others (1972) describe the mass-balance terminology, and Østrem and Brugman (1991) describe various data collection techniques, while Krimmel (1996) fully describes the techniques used at South Cascade Glacier. The seasonal mass-balance records started in 1959 for South Cascade Glacier and in 1966 for Wolverine and Gulkana Glaciers. The record for South Cascade Glacier is the longest seasonal mass-balance record in North America, and only a few longer records exist worldwide.

Numerous investigators have used these datasets to address key issues of glacier-climate fluctuations, as they represent a major component of the global glacier population. Meier (1984), Dyurgerov and Meier (1997, 2000) and Meier 


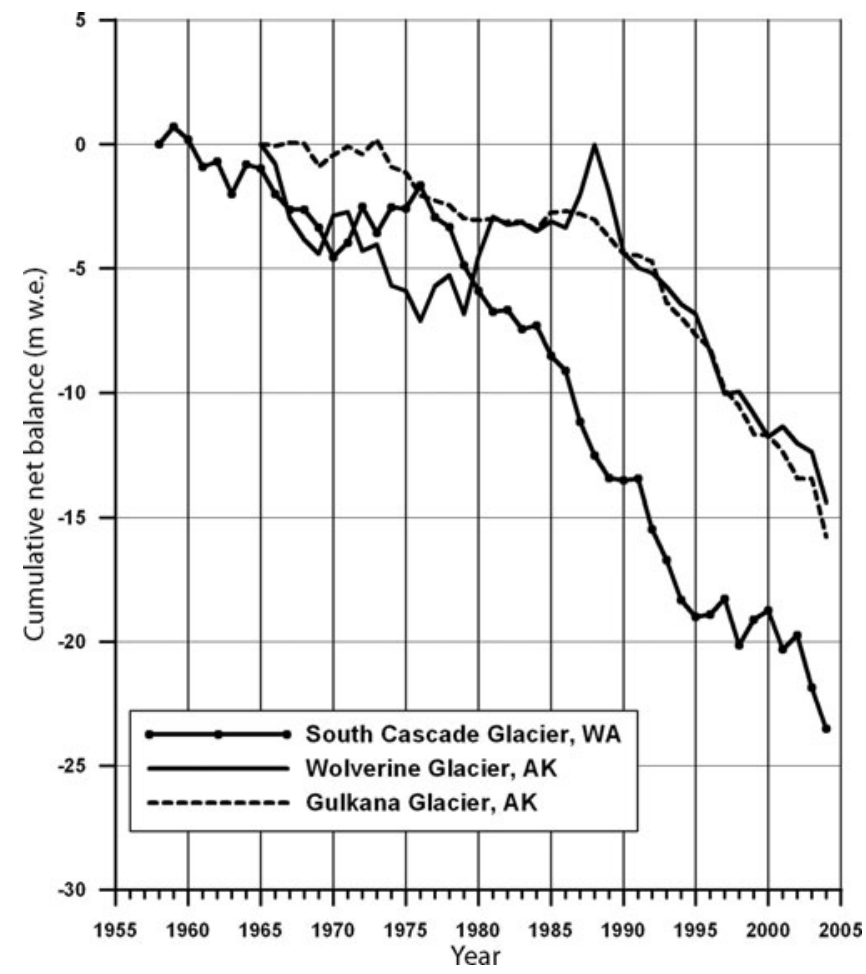

Fig. 1. Cumulative net balance for the entire measurement record for Wolverine, Gulkana and South Cascade Glaciers.

and others (2003) have used these datasets in global studies of the wastage of small mountain glaciers and their impact on global sea level. Rasmussen and Conway (2001, 2004) combined upper-air meteorological observations with these mass-balance observations to develop regional mass-balance models. New concepts and ways to interpret mass-balance data have resulted from the observations at South Cascade Glacier. Harrison and others $(2001,2003)$ characterized the response of a glacier to climate change with a single timescale based on the glacier geometry and mass balance.

These data have also been extensively used to investigate the relationship between glacier mass-balance and climate fluctuations as characterized by various indices, such as the Pacific Decadal Oscillation (PDO) and the Southern Oscillation Index (SOI). There is an extensive body of work on this subject (e.g. Walters and Meier, 1989; Hodge and others, 1998; Bitz and Battisti, 1999). These studies have shown that there exist strong correlations between fluctuations of climate and glacier mass balance, particularly for the maritime glaciers. In addition, there are significant interglacier correlations between the balances that represent patterns in atmospheric circulation. The mass-balance records are now 10-15years longer since many of these studies took place, and while many correlations remain unchanged, there are new trends and some changes in important correlations. Most importantly, all three glaciers now demonstrate a correlated negative mass balance, as observed globally for mountain glaciers (Dyurgerov and Meier, 2000).

\section{CHANGES IN NET BALANCE}

The net balance, the total mass lost or gained by a glacier, averaged over the surface of the glacier per year, clearly shows different and distinct long-term periods for all three
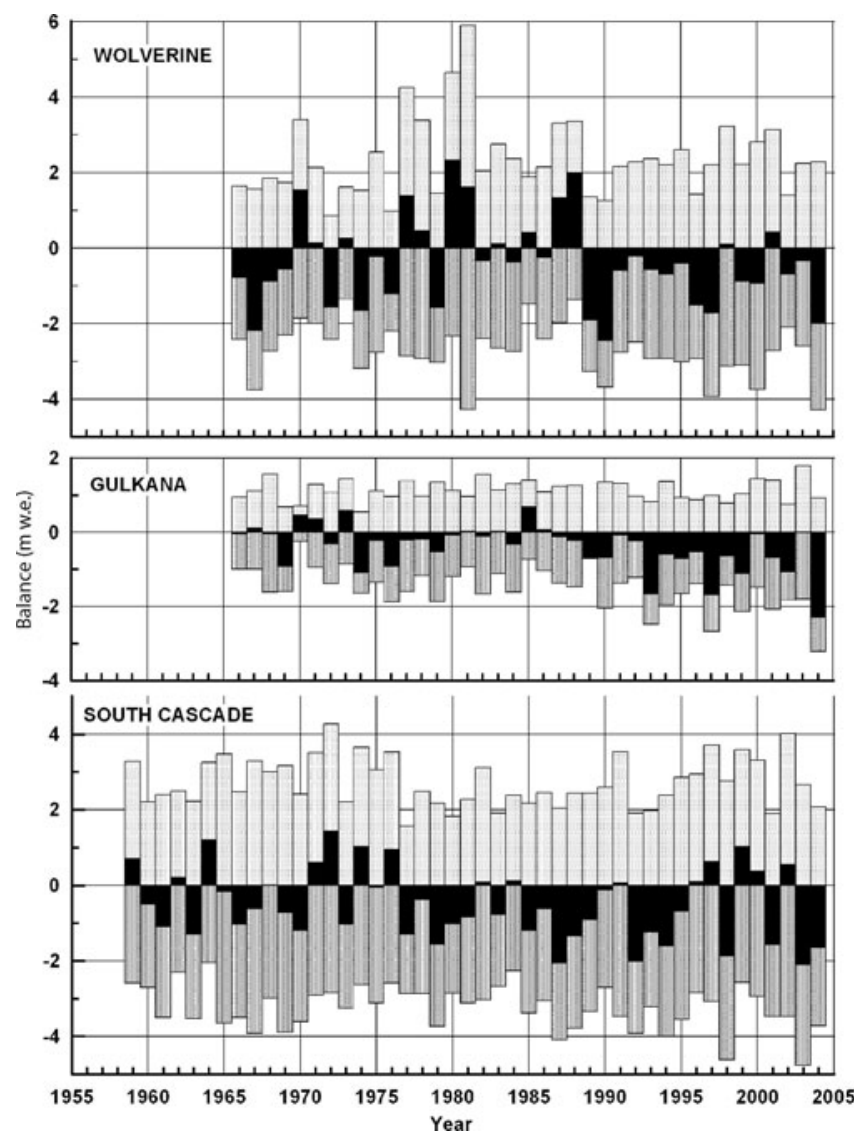

Fig. 2. The entire time series of measured winter balances (medium gray), summer balances (light gray) and net balances (black) for the three glaciers.

glaciers (Fig. 1). For South Cascade Glacier, there are four visually distinct periods evident in the record. For the period 1959-70, South Cascade Glacier lost 4.6 m w.e., while the period $1970-76$ is the only sustained positive period in the entire record, when the glacier gained $2.9 \mathrm{mw}$.e. It then entered an extended period of mass loss that spanned 197795 when it nearly monotonically lost $16.5 \mathrm{~m}$ w.e. The last period, 1995-2004, although still negative overall, was interspersed with a few positive years as well as some of the most negative years in the record. This negative trend in mass balance was characteristic of glaciers in the North Cascade Range. Measurements by the US National Park Service and others on as many as 14 glaciers during 19842000 indicated mass balance of those other North Cascade glaciers correlated ( $r=0.79-0.95$, average $r=0.87)$ with that of South Cascade Glacier (Pelto and Riedel, 2001). Finally, the overall wastage of South Cascade Glacier during 1959-2004 was qualitatively similar to the generalized glacier wastage in much of the Washington North Cascades (1959-98) reported by Granshaw and Fountain (2006).

For Wolverine Glacier, there are three distinct periods. The first period spans 1966-76, in which there was a negative mass-balance trend and the cumulative net balance was -7.1 mw.e. From 1976 to 1988, Wolverine gained $5.9 \mathrm{~m}$ w.e. The gain was not uniform, but the result of several years, 1980, 1981, 1987 and 1988, with large net balances generally in the range 1.5-2.0 m w.e. (Fig. 2). After 1988, Wolverine Glacier entered a period of nearly uniform mass loss that continued to 2004, with the glacier losing $14.4 \mathrm{~m}$ w.e. Gulkana Glacier, in the interior of Alaska, 
Table 1. South Cascade Glacier volume and rate-of-volume-change estimates

\begin{tabular}{lccc}
\hline Year & $\begin{array}{c}\text { Volume } \\
\mathrm{km}^{3}\end{array}$ & $\begin{array}{c}\text { Volume change } \\
\mathrm{km}^{3}\end{array}$ & $\begin{array}{c}\text { Rate of volume change } \\
\mathrm{km}^{3} \mathrm{a}^{-1}\end{array}$ \\
\hline About 1890 & 0.49 & -0.17 & -0.0045 \\
1928 & 0.32 & -0.08 & -0.0027 \\
1958 & 0.24 & -0.02 & -0.0017 \\
1970 & 0.22 & -0.03 & -0.0020 \\
1985 & 0.19 & -0.03 & -0.0019 \\
2001 & 0.16 & & \\
\hline
\end{tabular}

exhibited three different trends. The first was a short period, 1966-73, of almost static net balance. This was followed by a loss of $2.9 \mathrm{~m}$ w.e. during 1974-85. Then the trend became more negative, such that by 2004 Gulkana has lost an additional $12.8 \mathrm{~m}$ w.e.

A comparison of the records from all three glaciers (Fig. 1) shows that early in the record the net balance of each glacier behaved independently. In 1977, South Cascade Glacier began a nearly monotonic period of negative balance, which continued through 2004. Wolverine and Gulkana Glaciers followed in 1989 with comparable specific mass losses. The average net balance for South Cascade Glacier for the period 1977-2004 was $-0.78 \mathrm{~m}$ w.e., while the average net balance for Wolverine and Gulkana Glaciers for the period 1989-2004 was -0.90 and $-0.80 \mathrm{~m}$ w.e., respectively. Inspection of the period 2000-04, which is too short for meaningful statistics, suggests that the net balances are becoming more negative, thus following the current global trend in glacier wastage (Meier and others, 2003).

\section{GLACIER VOLUME}

The mass-balance record for a glacier only gives the rate of change of ice surface; ice volume estimates can be used to assess total water storage and for modeling glacier dynamics. Table 1 gives estimates of the ice volume for South Cascade Glacier from 1890 to 2001. Glacier surface extent and altitude in about 1890 were estimated on the basis of dated glacier moraines (Miller, 1968) and trimlines on the valley walls. An oblique photograph of the glacier from 1928 was used to estimate the glacier surface altitude for that year; for the remaining years, the glacier surface was mapped with stereo aerial photography or by optical surveying on the glacier. Regularly spaced glacier surface altitude grids were made from the maps or directly from photogrammetric analysis.

The glacier surface altitude grids, combined with bed topography from an ice-penetrating radar study and USGS 7.5' topographic maps, yielded South Cascade Glacier volumes ranging from $0.49 \mathrm{~km}^{3}$ in about 1890 , to $0.16 \mathrm{~km}^{3}$ in 2001 (Table 1). Inaccuracies in the bed topography and the photogrammetric analysis are greater than the glacieraverage annual changes typically measured with networks of ablation stakes. Hence, the volume changes cannot be
Table 2. Gulkana Glacier volume and rate-of-volume-change estimates

\begin{tabular}{lccc}
\hline Year & $\begin{array}{c}\text { Volume } \\
\mathrm{km}^{3}\end{array}$ & $\begin{array}{c}\text { Volume change } \\
\mathrm{km}^{3}\end{array}$ & $\begin{array}{c}\text { Rate of volume change } \\
\mathrm{km}^{3} \mathrm{a}^{-1}\end{array}$ \\
\hline $1890 \pm 15$ & 3.40 & -0.702 & -0.0084 \\
1974 & 2.70 & -0.101 & -0.0057 \\
1993 & 2.59 & -0.083 & -0.0139 \\
1999 & 2.51 & & \\
\hline
\end{tabular}

used for annual mass-balance determinations, but rather to give estimates of long-term changes and to check the cumulative mass balance for bias errors. From about 1890 to 1928 the glacier lost $35 \%$ of its volume, at an average rate of $-0.0045 \mathrm{~km}^{3} \mathrm{a}^{-1}$, while from 1928 to 2001 the glacier lost $50 \%$ of its remaining volume, at an average rate of $-0.002 \mathrm{~km}^{3} \mathrm{a}^{-1}$.

The volume of Gulkana Glacier was estimated using procedures similar to those used for South Cascade Glacier, and is given in Table 2. The area and surface height distribution of Gulkana Glacier in about 1890 were estimated primarily by filling the void between the height of dated trimlines and the current-day ice surface with an imaginary ice mass with the same surface shape as the current glacier. The 1974 volume was estimated by assuming the average ice thickness was $147 \mathrm{~m}$, which is the average of 19 ice radar measurements made in 1976. Other volumes are determined from the estimated 1974 volume and the measured volume changes. Area and surface height distribution in 1974, 1993 and 1999 were measured photogrammetrically using stereo vertical photography (Cox and March, 2004). The volume of Gulkana Glacier in 1890 was an order of magnitude greater than that of South Cascade Glacier (Tables 1 and 2), and the rate of volume loss also has been substantially greater for Gulkana than for South Cascade Glacier. The fraction of volume lost has been much greater for South Cascade than for the larger Gulkana Glacier. South Cascade Glacier lost $67 \%$ of its volume during 1890-2001, whereas Gulkana Glacier lost 26\% of its volume during 1890-1999.

\section{TRENDS IN SEASONAL BALANCES}

The cumulative net balance clearly shows the overall trends, and the winter, summer and net balance $\left(b_{\mathrm{w}}, b_{\mathrm{s}}\right.$ and $\left.b_{\mathrm{n}}\right)$ time series (Fig. 2) provide additional information on glacier fluctuations in response to climate variations. The trends in the seasonal balances, given here as millimeters water equivalent per year $\left(\mathrm{mm} \mathrm{a}^{-1}\right)$, are not as apparent as in the cumulative net balance, and we used a Mann-Kendall test for trend, with statistical significance level stated in terms of percent probability of incorrectly rejecting the null hypothesis that no trend exists. Slopes of statistically significant trends were evaluated using Sen's non-parametric estimator of slope (Gilbert, 1987).

We carried out the test on the entire period of record for the seasonal balances from each glacier and then for the interval 1989-2004, where 1989 corresponds to the year 


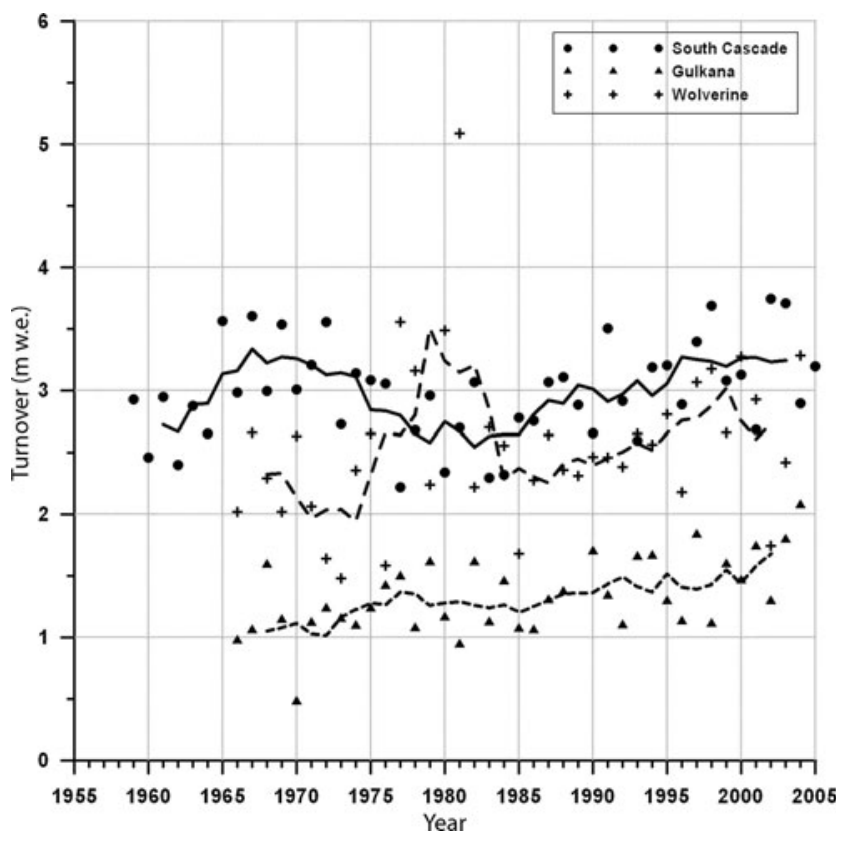

Fig. 3. The annual turnover for the three glaciers; the lines are 5 year running averages.

when cumulative net balance of all three glaciers began the synchronous decline (Fig. 1) and to a moderate shift in the PDO (Rodionov, 2004). Trends were not detected in the winter balance or in the summer balance for the period 1989-2004, except for Wolverine Glacier, where the winter balance trend of $51.0 \mathrm{~mm} \mathrm{a}^{-1}$ was detected at the $10 \%$ significance level. One possible reason for the lack of detection of simple linear trends in winter balance could be confounding effects on precipitation due to low-frequency variations of conditions in the northeast Pacific Ocean. Negative trends in the summer balance for the period of record were detected at the 5\% significance level for the two Alaskan glaciers and at the $10 \%$ significance level for South Cascade Glacier. The summer balance trends during 1966-2004 were -21.0 and $-23.0 \mathrm{~mm} \mathrm{a}^{-1}$ for Wolverine and Gulkana Glaciers, respectively, and the summer balance trend during 1959-2004 for South Cascade Glacier was $-18.1 \mathrm{~mm} \mathrm{a}^{-1}$.

That summer climate conditions became progressively more conducive to mass loss, probably due to warming, is also seen in the fact that many of the most negative summer balances at each glacier occurred during later years. Eight of the ten most negative summer balances of the Gulkana Glacier record occurred during 1989-2004, and the corresponding numbers of summer balances for Wolverine and South Cascade Glaciers were seven and five, respectively.

Investigators have found substantial declines in the snow water equivalent in the Pacific Northwest by analyzing observations from the US Natural Resources and Conservation Service (NRCS) snow-course and automated SNOTEL networks (Mote, 2003; Mote and others, 2005). The winter balance of South Cascade Glacier does not exhibit a similar negative trend, which is likely due partly to the glacier's high altitude. The altitude of South Cascade Glacier ranges from about 1600 to $2100 \mathrm{~m}$, while most NRCS sites are at lower altitude. Mote (2003) found that the decline in snow water equivalent has been greatest below $1800 \mathrm{~m}$. The South Cascade Glacier trend analysis results are consistent with
Table 3. Trends in annual turnover $\left(\mathrm{mm} \mathrm{a}^{-1}\right)$ for each glacier for the period of record and for 1989-2004

\begin{tabular}{lccc}
\hline Period & South Cascade & Glacier Wolverine & Gulkana \\
\hline Entire record & 17 & 14 \\
$1989-2004$ & 51 & \\
\hline
\end{tabular}

the results of a study by Hamlet and Lettenmaier (1999) that showed that for future climate scenarios the Cascade Mountains will receive approximately the same amount of precipitation, but less snow because it will be warmer. Thus, the lack to date of a negative trend in the winter balance of South Cascade Glacier is likely at least partly the result of the altitude of the glacier which reduces the impact of increasing winter temperature.

\section{GLACIER TURNOVER}

The annual turnover of glacier mass, the average of the absolute values of the winter and summer balance (Meier, 1984; Dyurgerov and Meier, 2000), is a measure of the flux of water through a glacier system, and it reflects intensity of hydrologic cycling through that system. As expected, annual turnover, expressed in m w.e., of the two maritime glaciers, South Cascade and Wolverine Glaciers, is about twice as great as that of the more continental Gulkana Glacier (Fig. 3). In addition, there appear to be positive trends in annual turnover, particularly from the late 1980 s to 2004 . To test for trends, we carried out a Mann-Kendall test for the entire period of record of each glacier, and for the period 19892004, and the results are given in Table 3. For the period of record, we found positive trends of annual turnover for Wolverine and Gulkana Glaciers, at a 5\% significance level, but no trend for South Cascade Glacier. For the period 19892004, a positive trend was detected for Wolverine Glacier at the $10 \%$ significance level. The rate of increase in annual turnover is given in Table 3, and ranges from 14 to $51 \mathrm{~mm} \mathrm{a}^{-1}$, which is substantially higher than the global average for small glaciers, of $0.9 \mathrm{~mm} \mathrm{a}^{-1}$ computed by Dyurgerov and Meier (2000) using data from 1961 through 1997.

\section{INTER-GLACIER AND GLACIER-CLIMATE CORRELATIONS}

The addition of 10 years or more of mass-balance data beyond previous investigations allows us to reassess relationships between the glacier balances and also between the balances and climate indices. We computed the correlations between the winter balances for all three glaciers, first for the period 1966-88 and then for 1989-2004. For the first period we found significant correlation of -0.62 between the South Cascade Glacier and Wolverine Glacier winter balances. For the second period, the correlation changed from -0.62 to -0.26 , indicating winter balance of South Cascade Glacier as less strongly but still negatively correlated with winter balance of Wolverine Glacier, which indicates a possible change in the winter accumulation patterns.

It is well known that the atmospheric circulation over the northeast Pacific has a strong impact on the winter accumulation on the maritime glaciers of this study, (Walters 
and Meier, 1989; Hodge and others, 1998; Bitz and Battisti, 1999). The fluctuations in climate can be represented by any one of several indices. In this study, we used the PDO (Mantua and others, 1997) to represent climate conditions in the northeast Pacific. The PDO is defined as the leading principal component of North Pacific monthly sea-surface temperature variability north of $20^{\circ} \mathrm{N}$, and warm or cold phases of the PDO can persist for 10 years or more. The values are available from the Joint Institute for the Study of the Ocean and the Atmosphere, University of Washington, Seattle, WA, USA (http://jisao.washington.edu/pdo/ PDO.latest).

To re-examine the links between glacier mass balance and circulation in the northeast Pacific, we computed correlations between the winter average PDO for December-March and the winter balances for the maritime South Cascade and Wolverine Glaciers. By using three time periods, the period of record, 1966-88 and 1989-2004, we found a significant change in the relationship between the PDO and the winter balances of Wolverine Glacier, but less so for South Cascade Glacier. Table 4 shows that while there are strong correlations for the period of record in all cases, the strength of the correlations is considerably lower for the 1989-2004 period. Note that the sign of the correlation coefficient is negative for South Cascade Glacier and positive for Wolverine, which indicates the welldocumented, inverse accumulation pattern driven by changes in storm tracks between warm and cool PDO excursions (Walters and Meier 1989). During cool PDO periods, winter storms are directed towards Washington State, thus increasing the winter balance at South Cascade Glacier. During warm PDO periods, conditions in the northeast Pacific steer the winter storms into Alaska, increasing the winter balance at Wolverine. The correlations for Wolverine Glacier with the PDO for the period 19892004 have become very weak, while the correlations for South Cascade Glacier remain strong. The winter balance of continental Gulkana Glacier did not correlate with the PDO, a result of the mountain ranges to the south blocking incoming precipitation

Previous research has shown that winter balance fluctuations of maritime glaciers dominate the net balance fluctuations (Hodge and others, 1998). As summer balances of the benchmark glaciers have become more negative during recent years, a result of warmer, drier summers, summer balance has taken on a greater role in determining glacier net balance. For 1998, 2001, 2003, 2004 and 2005, the entire winter snow accumulation was completely melted from South Cascade Glacier. Furthermore, preliminary results for 2005 show that the 2005 summer balance is likely to be the most negative on record. The combined impact of warmer drier summers and less snow on the lower portion of the glacier has resulted in some of the most negative net balances on record.

\section{SUMMARY}

More than 40 years of net and seasonal mass-balance measurements by the USGS for South Cascade, Wolverine and Gulkana Glaciers show annual and interannual fluctuations that reflect the controlling climatic conditions. Overall trends in net balance of all three glaciers since the start of monitoring have been negative, and since 1988 net balance of the three has trended almost exclusively negatively.
Table 4. Coefficient of correlation between the winter balances of South Cascade and Wolverine Glaciers and the winter-averaged PDO (December-March), for the entire period of the mass-balance record and the periods 1966-88 and 1989-2004

\begin{tabular}{lrrr}
\hline Glacier & Entire record & 1966-88 & 1989-2004 \\
\hline South Cascade & -0.61 & -0.79 & -0.65 \\
Wolverine & 0.53 & 0.62 & 0.28 \\
& & & \\
\hline
\end{tabular}

Increasingly negative summer balance at all three glaciers, accompanied by increasing annual mass turnover, indicates that the intensity of the hydrologic cycle governing the glaciers has increased in response to climate change (Bosilovich and others 2005). Although trends in winter balance have not yet been detected, summer balances have been responding to warmer melt-season temperatures or increased melt-season duration. Finally, the decrease in correlations between the winter balances at Wolverine Glacier and the PDO suggests that a decoupling of PDO from winter balance may be occurring, which could be a sign that the former is being overwhelmed by general warming.

\section{ACKNOWLEDGEMENTS}

We gratefully acknowledge all of the individuals whose dedication has made this unique and invaluable record possible. We particularly acknowledge R. Krimmel and D. Trabant not only for their dedication, but also for their mentorship on carrying out a mass-balance program. We also thank A. Rasmussen for his stimulating discussions on glacier mass balance and its interpretation.

\section{REFERENCES}

Arendt, A.A., K.A. Echelmeyer, W.D. Harrison, C.S. Lingle and V.B. Valentine. 2002. Rapid wastage of Alaska glaciers and their contribution to rising sea level. Science, 297(5580), 382-386.

Bidlake, W.R., E.G. Josberger and M.E. Savoca. 2005. Water, ice, and meteorological measurements at South Cascade Glacier, Washington, balance year 2003. USGS Sci. Invest. Rep. 2005-5210.

Bitz, C.M. and D.S. Battisti. 1999. Interannual to decadal variability in climate and the glacier mass balance in Washington, Western Canada, and Alaska. J. Climate, 12(11), 3181-3196.

Bosilovich, M.G., S.D. Schubert and G.K. Walker. 2005. Global changes of the water cycle intensity. J. Climate, 18(10), 1591-1608.

Cox, L.H. and R.S. March. 2004. Comparison of geodetic and glaciological mass-balance techniques, Gulkana Glacier, Alaska, U.S.A. J. Glaciol., 50(170), 363-370.

Dyurgerov, M.B. and M.F. Meier. 1997. Year-to-year fluctuations of global mass balance of small glaciers and their contribution to sea-level changes. Arct. Alp. Res., 29(4), 392-402.

Dyurgerov, M.B. and M.F. Meier. 2000. Twentieth century climate change: evidence from small glaciers. Proc. Natl. Acad. Sci. (PNAS), 97(4), 1406-1411.

Gilbert, R.O. 1987. Statistical methods for environmental pollution monitoring. New York, John Wiley \& Sons.

Granshaw, F.D. and A.G. Fountain. 2006. Glacier change (19581998) in the North Cascades National Park Complex, Washington, USA. J. Glaciol., 52(177), 251-256.

Hamlet, A.F. and D.P. Lettenmaier. 1999. Effects of climate change on hydrology and water resources in the Columbia River basin. J. Am. Water Res. Assoc., 35(6), 1597-1623. 
Harrison, W.D., D.H. Elsberg, K.A. Echelmeyer and R.M. Krimmel. 2001. On the characterization of glacier response by a single time-scale. J. Glaciol., 47(159), 659-664.

Harrison, W.D., C.F. Raymond, K.A. Echelmeyer and R.M. Krimmel. 2003. A macroscopic approach to glacier dynamics. J. Glaciol., 49(164), 13-21.

Hodge, S.M., D.C. Trabant, R.M. Krimmel, T.A. Heinrichs, R.S. March and E.G. Josberger. 1998. Climate variations and changes in mass of three glaciers in western North America. J. Climate, 11(9), 2161-2179.

Krimmel, R.M. 1996. Glacier mass balance using the grid-index method. CRREL Spec. Rep. 96-27, 62-68

Mantua, N.J., S.R. Hare, Y. Zhang, J.M. Wallace and R.C. Francis. 1997. A Pacific interdecadal climate oscillation with impacts on salmon production. Bull. Am. Meteorol. Soc., 78(6), 1069-1079.

March, R.S. 1998. Mass balance, meteorological, ice motion, surface altitude, and runoff data at Gulkana Glacier, Alaska, 1994 balance year. USGS Water-Res. Invest. Rep. 97-4251.

Mayo, L.R., M.F. Meier and W.V. Tangborn. 1972. A system to combine stratigraphic and annual mass-balance systems: a contribution to the International Hydrological Decade. J. Glaciol., 11(61), 3-14.

Mayo, L.R., D.C. Trabant and R.S. March. 2004. A 30-year record of surface mass balance (1966-95) and motion and surface altitude (1975-95) at Wolverine Glacier, Alaska. USGS Open File Rep. 2004-1069.

Meier, M.F. 1984. Contribution of small glaciers to global sea level. Science, 226(4681), 1418-1421.

Meier, M.F., W.V. Tangborn, L.R. Mayo and A. Post. 1971. Combined ice and water balances of Gulkana and Wolverine Glaciers, Alaska, and South Cascade Glacier, Washington, 1965 and 1966 hydrologic years. USGS Prof. Pap. 715-A.
Meier, M.F., M.B. Dyurgerov and G.J. McCabe. 2003. The health of glaciers: recent changes in glacier regime. Climatic Change, 59(1-2), 123-135.

Miller, C.D. 1968. Chronology of neoglacial moraines in the Dome Peak area, North Cascade Range, Washington. Arct. Antarct. Alp. Res., 1(1), 49-65.

Mote, P.W. 2003. Trends in snow water equivalent in the Pacific Northwest and their climatic causes. Geophys. Res. Lett., 30(12), 1601. (10.1029/2003GL017258.)

Mote, P.W., A.F. Hamlet, M.P. Clark and D.P. Lettenmaier. 2005. Declining mountain snowpack in western North America. Bull. Am. Geogr. Soc., 86(1), 39-49.

Østrem, G. and M. Brugman. 1991. Glacier mass-balance measurements. A manual for field and office work. Saskatoon, Sask., Environment Canada. National Hydrology Research Institute. (NHRI Science Report 4.)

Pelto, M.S. and J. Riedel. 2001. Spatial and temporal variations in annual balance of North Cascade glaciers, Washington, 19842000. Hydrol. Process., 15(18), 3461-3472.

Rasmussen, L.A. and H. Conway. 2001. Estimating South Cascade Glacier (Washington, U.S.A.) mass balance from a distant radiosonde and comparison with Blue Glacier. J. Glaciol., 47(159), 579-588.

Rasmussen, L.A. and H. Conway. 2004. Climate and glacier variability in western North America. J. Climate, 17(9), 1804-1815.

Rodionov, S.N. 2004. A sequential algorithm for testing climate regime shifts. Geophys. Res. Lett., 31(9), L09204. (10.1029/ 2004GL019448.)

Walters, R.A. and M.F. Meier. 1989. Variability of glacier mass balances in western North America. In Paterson, D.H., ed. Aspects of climate variability in the Pacific and western Americas. Washington, DC, American Geophysical Union, 365-374. 